\title{
Fin-de-Siècle and Motion Sickness in Florence Marryat's The Blood of the Vampire ${ }^{1}$
}

\section{Florence Marryat'in The Blood of the Vampire Romanında Baş Döndürücü Bir Yüzyll Sonu}

\author{
Ayşe Naz BULAMUR*
}

\begin{abstract}
In Florence Marryat's The Blood of the Vampire (1897), the nineteen-year-old orphaned heiress, Harriet Brandt, embodies the social turbulence of the fin de siècle with her shifting identity as a human and vampire, British and Jamaican, a former convent girl with dubious sexual orientation, and nurturer and killer of her loved ones. The white upper-class guests of Hotel Lion d'Or, a seaside resort in Belgium, feel motion sickness due to her multiethnic and interspecies identity that shakes patriarchy, scientific authority, and Orientalist cultural distinctions. They feel nausea because they are disturbed with her "unrefined" blood, unexplainable psychic powers, and sexual decadence that contaminates the hotel. The people Harriet cares for at the hotel-a baby girl and her husband Anthony-die due to her uncontrollable ability to drain the life energy of those close to her. Harriet's loved ones gradually die because they are not "fit" to survive in fin-de-siècle Europe, where racial and gender categories were becoming unstable. Her suicide after unwittingly killing her newlywed husband suggests that she herself cannot embrace her liminal identity. In the novel, sickness serves as a metaphor for the social disorientation of the fin de siècle that takes the lives of Victorians, who cannot adapt to changing sociopolitical conditions.
\end{abstract}

Keywords: Florence Marryat, The Blood of the Vampire, sickness, identity, and fin-de-siècle

Öz

Florence Marryat'ın The Blood of the Vampire (1897) romanında on dokuz yaşındaki Harriet Brandt, vampir ve insan, İngiliz ve Jamaikalı, seven ve öldüren ve gizemli cinsel kimliğiyle on dokuzuncu yüzyıl sonu Avrupa'sındaki kültürel değişim ve türbülansı temsil etmektedir. Belçika'nın sahilinde Hotel Lion d'Or'da konaklayan zengin Avrupalılar Harriet'ın ataerkil düzeni, bilimin üstünlügünü ve ırkçı söylemleri altüst eden çok kültürlü kimliği karşısında adeta hastalanır. Harriet'ın oteli kirlettiğine inandıkları melez kanı, doğa üstü güçleri ve cinsel özgürlüğü karşısında başları döner ve mideleri bulanır. Sevdiklerinin hayat enerjisini istemsiz bir şekilde içine çekmesi yüzünden otelde sevip okşadığı bir bebek ve kocası Anthony yavaş yavaş hastalanır ve ölür. Harriet'ın yakınları, on dokuzuncu yüzyıl sonunda tür, ırk ve cinsiyet kategorilerini sarsan çalkantıya uyum sağlayamadıkları için ölür. Kontrol edemediği ruhani güçleri yüzünden balayında kocasını öldürdükten sonra intihar eder çünkü tabuları kıran, değişken ve arada derede kimliğini kendi de kabul edememiştir. Bu makale, romanda hastalığın yüzyıl sonunun baş döndürücü etkisini vurgulayan bir metafor olduğunu ve Victoria İngiltere'sinin değişen sosyal ve politik atmosferine ayak uyduramayanları öldürdüğünü savunur.

Anahtar Kelimeler: Florence Marryat, The Blood of the Vampire, hastalık, kimlik, yüzyıl sonu

\section{Introduction}

Florence Marryat's novel The Blood of the Vampire (1897) reflects the cultural crisis, fragmentation, and social disintegration of the fin de siècle through the nineteen-year-old orphaned heiress Harriet Brandt, who disrupts categories of race, gender, and species due to her ambivalent identity as British-Jamaican, human and vampire, and sexual decadent with a religious upbringing. Victorian norms were in flux at the turn of the century, the period Raymond Williams (1963) characterizes as an interregnum. Sally Ledger (1995) writes: "The collision between the old and the new that characterized the fin de siècle marks it as an excitingly volatile transitional period; a time when British cultural politics were caught between two ages, the Victorian and the modern; a time fraught both with anxiety and with an exhilarating sense of possibility" (p. 22). As the epitome of the fin de siècle, the single female traveler from Ja-

\footnotetext{
${ }^{1}$ The extended version of this article was published as the fourth chapter of my book Victorian Murderesses: The Politics of Female Violence (Cambridge Scholars Publishing, 2016). Published with the permission of Cambridge Scholars Publishing. This article is financially supported by Boğaziçi University Research Fund (BAP) Grant Number 7680.

* Assoc. Prof. Dr., Boğaziçi University, Faculty of Arts and Sciences, Department of Western Languages and Literatures, naz.bulamur@boun.edu.tr
} 
maica at Hotel Lion d'Or, a seaside resort in Belgium, threatens the lives of the European guests, who are shaken by her racial hybridity, promiscuity, as well as by the rumors that her Creole $^{2}$ grandmother had been bitten by a vampire bat. Indeed, along with the nurses at the convent in Jamaica, the people Harriet cares for in Europe-Margaret Pullen's baby girl and her husband Anthony Pennell- die due to her involuntary and uncontrollable ability to drain the life energy of those close to her. I argue that the characters get sick and die because they are not "fit" 3 to survive in fin-de-siècle Europe, where racial and gender categories were becoming unstable. Indeed, Harriet's suicide after unwittingly killing her newlywed husband suggests that she herself cannot tolerate the turbulence of the fin de siècle, which she embodies with her liminal identity. The female traveler from the West Indies nauseates the hotel guests by violating the domestic ideology, defying science with her superhuman powers, and by calling into question the racial purity of Victorian England.

"It was widely believed that society was sick" because the New Woman destabilized traditional gender roles (Cunningham, 1978, p. 1); Harriet is the New Woman of the 1890s who inflicts Victorians with her allegedly unfeminine traits of self-confidence and independence. Marryat's representation of the New Woman as a psychic vampire shows how selfassertive and powerful women were regarded as contagious creatures that spread sickness and death. For example, Janet Hogarth (1897) complains that the New Woman afflicts Londoners by calling for gender equality; Elizabeth Linton (1891-1892) writes that the New Woman imperils the society as "a wild woman, a blasphemer against "Nature, God, and Good" (as cited in Ardis, 1990, pp. 20-1). Ella Winston (1896), on the other hand, denies the sociopolitical existence of the New Woman by comparing her to a "sea-serpent, [...] largely an imaginary creature" (p. 170). Marryat's novel pictures the New Woman as half-human and half-vampire to show how nonconformist women were demonized as "sick," "evil," and "vampiric" (Macfie, 1991, p. 66).

Although Marryat successfully intertwines Harriet's vampirism with the feminist movements of the 1890s, Victorian critics dismissed her novel as a poor imitation of Bram Stoker's Dracula (1897) due to its lack of gruesome scenes that are common in gothic fiction. Published in the same year, Blood surpasses Dracula in thrill by locating vampirism, not in the remote medieval castles of Transylvania, but in hotels, which stand for Europe's modernity and progress. What intensifies the thrill is that Harriet is not an archetypal blood-drinking vampire that sleeps in coffins, but a beautiful and an affectionate woman both men and children adore. She first captivates the heart of Captain Ralph, the fiancé of another hotel guest, Elinor Leyton, and later marries his cousin Anthony. She seems to be a perfect mother figure, as she volunteers to babysit Margaret Pullen's daughter. The dichotomy between her charming appearance and her unpredictable power to kill makes her even more frightening than her predecessors, who rise from the dead and drink blood.

If not an undead blood-sucking vampire, Harriet is monstrous because her hybridity alarms the Victorians by suggesting that identity is not fixed, but "a matter of "becoming" (Hall, 1996, p. 112) and is "always in transit" (Ong, 1999, p. 2). Her liminal identity embodies the turbulence of the fin de siècle, which Homi Bhabha (1994) explains in The Location of Culture:

\footnotetext{
2 “'A 'Creole' is one born in the Americas whose parents, of whatever race, were born elsewhere" (Brody, 1998, pp. 56-57).

${ }^{3}$ I rely on Charles Darwin's (2002) argument that only the most fit individuals survive the struggle for existence. The novel echoes Darwin's theory of the survival of the fittest, since the characters, who are not fit for the turbulence of the fin de siècle, die.
} 
[...] in the fin de siècle, we find ourselves in the moment of transit where space and time cross to produce complex figures of difference and identity, past and present, inside and outside, inclusion and exclusion. For there is a sense of disorientation, a disturbance of direction, in the 'beyond': an exploratory, restless movement caught so well in the French rendition of the words au-delá -here and there, on all sides, fort/da, hither and thither, back and forth. (p. 2)

In Blood, the hotel guests feel nausea due to their sense of disorientation at Harriet's shifting identity that travels back and forth between diverse categories of race and species. Her multiethnic identity is disturbing because it serves as a contact zone (Pratt, 1992) between the socalled civilized England and its bestial colonies. Indeed, her mixed blood points out the daunting fact that Europe is not homogeneously white. In the absence of physical violence, what renders the story scary is Harriet's unclassifiable identity that challenges scientific authority as well as Orientalist cultural distinctions. Her violation of rigid gender, scientific, and racial categories, then, stands for the "restless movement" of the fin de siècle that inflicts the characters with motion sickness. What makes them sick is their realization that identity is unstable and always on the move. It is Harriet's traveling identity that nauseates her bourgeois circle. Harriet, then, is not only a vampire that kills for survival, but a social and historical agent who shows how Victorians, including herself, are shaken by the turmoil of the fin de siècle.

Ironically, the articles on Marryat's neglected novel discuss vampirism and sickness literally not metaphorically. Alexandra Warwick (1995) traces the connection between infection and gender; Susan Zieger (2008) describes Harriet's need for intimacy as an addiction to love; Sian Macfie (1991) writes how women with venereal diseases were regarded as vampires. There are also numerous studies that examine Harriet's psychic powers in light of medical discourses: Zieger (2008) argues that "Marryat medicalizes Harriet's vampirism" (p. 216) by having a physician investigate her heredity; Brenda Hammack (2008) observes that "Marryat's portrait of a female vampire reads like a medical case study" (p. 886). In her introduction to the novel, Greta Depledge (2010) states that "male medical authority" (p. xvi) controlled transgressive women in Victorian England. Octavia Davis (2007) also writes that Victorian medicine represents women as vampiric because they replenish the blood and energy they lose during menstruation and childbirth by drawing on the vitality of others. As valuable as these studies are, they reduce Blood to a medical study and overlook how the trope of infection is a metaphor for the social anxiety and restlessness at the turn of the century. The following three sections discuss how Harriet's racially hybrid and intra-species identity, which does not fit into traditional female roles, stands for the turbulence of the fin de siècle that causes motion sickness.

\section{The New Vampiric Woman}

Marryat endorses a matrilineal lineage, as Harriet inherits her "weakening and debilitating effect" (p. 162) from her grandmother, and not from a powerful male figure like Dracula. The vampire blood that Harriet inherits from her matriarchs metaphorically destroys the marriage institution, as her husband and the infant she nurses at the hotel gradually weaken and die. Harriet creates motion sickness for Victorian readers by destabilizing traditional female roles with her dubious sexual orientation, her uncontrollable appetite for food and sex, and her alternating role as an affectionate woman and a murderess. Blood is horrifying because it endorses the Victorian fear that the sexually decadent and financially free New Woman threaten male supremacy.

James Ashcroft Noble (1895) describes female sexual desire in the New Woman fiction as "sickening" (p. 494); Harriet's uncontrollable appetite for food and sex makes the Victorian ladies ill. Elinor Leyton literally has motion sickness upon hearing that Harriet travels alone and has a room of her own: "[...] it sounds very improper! When I look up and down 
the table d'hôte menagerie sometimes it makes me quite ill!" (p. 9). She claims to "get neuralgia" whenever she is with Harriet, who leaves her in low spirits (p. 39). Elinor's perception of Harriet as a contagious woman stands for the Victorian assumption that the New Woman afflicts society with her sexual decadence. Cast as "an epitome of lust" (p. 71), Harriet, with her "full crimsom lips" (p. 38) and "yearning, passionate eyes" (p. 36), counters William Acton's description of "the angel of the house" in 1857: "Love of home, children, and domestic duties, are the only passions they feel...As a general rule, a modest woman seldom desires any sexual gratification for herself" (as cited in Ledger, 1997, p. 101). An indicator of sexual impurity and vulgarity, Harriet's excessive eating also makes Elinor sick: "I never saw anyone in society gobble her food in such a manner! She made me positively sick!" (p. 6). She is repelled by Harriet because she "devour[s] her food with so much avidity and enjoyment" (p. 4 ), emotions which are inappropriate for women. Harriet's gratification of her desire for food and sex is disturbing because it unsettles the assumption that angelic Victorian women do not have any bodily needs.

Harriet's "beastly" appetites are awakened in Hotel Lion d'Or that serves as a metaphor for her animalistic desires, both with its name and with the two gilded lions at the lobby. Bettina Matthias (2004) writes that the hotel is a "space for female self-realization and sexual liberation" since "hotels offer some sort of erotically charged promise to the female protagonists and limited freedom to act on it as they are exposed to new guests, especially to men, all the time, and as they move effortlessly between bedrooms and social halls" (p. 330). Marryat's single female traveler with a strict religious upbringing discovers her sexual desires at the hotel, where she has a room of her own, which is "a medium of self-expression, a catalyst of experience, a precondition of emancipation" (Heilmann, 2000, p. 179). The hotel guests find it strange that Harriet does not share a room with her travel mate, Olga, who cannot keep her under surveillance. Her private room as well as her temporary stays at hotels disturb domestic ideology that imprisons women within the Victorian home.

The noncommittal and transitory space of the hotel (Matthias, 2004) also stands for Harriet's shifting sexual orientation that appeals to men as well as women, who feel sick to discover their same sex desires. Sian Macfie (1991) writes that "vampirism came to be associatively linked with the notion of a moral contagion and especially with the 'contamination' of lesbianism" (p. 60); Harriet too seems vampiric for attracting the hotel guest, Margaret Pullen:

She had become fainter and fainter as the girl leaned against her with her head upon her breast. Some sensation which she could not define, nor account for-some feeling which she had never experienced before - had come over her and made her head reel. She felt as if something or someone were drawing all her life away. (p. 18)

The sensation Margaret feels upon Harriet's approach is unnamable because the term homosexuality did not exist until 1869; it was criminalized in England in 1885. The proper Victorian mother and wife becomes fainter due to her sudden realization that she has the "decadent" desires, for which writers like Oscar Wilde were imprisoned. Margaret's sickness, however, merges with sexual desire as she is struck by Harriet's passionate look: "[...] —it was so full of yearning affection - almost of longing to approach her nearer, to hear her speak, to touch her hand! It amused her to observe it!" (p. 23). The pauses in the sentence unravel the narrator's difficulty in explaining an unnamed and repressed feeling. The narrator discloses Margaret's "unaccountable affections" (p. 23) for Harriet by noting that her hypnotizing gaze makes Margaret feel as if she would burst into flame. What makes Margaret dizzy is her realization that she is taken in by Harriet, who violates Victorian sexual codes with her dubious sexual orientation. 
She disturbs the hotel guests not only with her fluid sexual desires, but also with her ambivalent role as the babysitter and the killer of Margaret's baby daughter, Ethel. Harriet's nurturance turns infanticidal as she thrives on the life energy of Ethel, whose "half-awed, half-interested expression" suggests that she is quite taken by her murderess (p. 28). Whereas Elinor keeps Ethel from the "wild beast" (p. 41), her future sister-in-law, Margaret, is pleased that her daughter is not scared of a stranger: "'She certainly does seem wonderfully good with you,' she observed presently. 'I never knew her so quiet with anybody but her nurse or me before" (p. 29). Ethel's attachment to her murderess reverses the mother-child relationship, as the baby becomes Harriet's nurturer. Indeed, the more she nurses Ethel, the handsomer she looks. Her cheeks glow with "a delicate flush," while the baby grows paler and eventually dies of fever. Even the sight of an infant drives Harriet wild because babies are source of nutrition: "O! let me hold her! let me carry her! I must!" (p. 14), she says, and her travel mate Olga jokes that Harriet would like to eat all the children she kisses at the hotel. Harriet defies "the notion that women are most gratified by feeding and nourishing others, not themselves" (Bordo, 1993, p. 118) by simultaneously loving and killing Margaret's baby.

Harriet's love for her husband Anthony too turns deadly as she unwittingly kills him during their honeymoon in Florence and, in doing so, unsettles the Victorian perception of the honeymoon as a means of sexually educating couples and of Italy as a romantic getaway. Helena Michie (2001) defines the Victorian understanding of the honeymoon "as the privileged scene of instruction" for the virgin or asexual brides. She highlights the importance of "geographical sites" in the newlywed couple's sexual education by stating that upper-middle-class honeymoons often involved "a journey away from familiar landscapes to a place that thematized otherness in its very terrain" (p. 234). The virginal female body can be transformed into being "legibly sexual" in a landscape that is allegedly free from the Victorian ideals of moral propriety. Harriet shatters the myth of Italy as a romantic honeymoon destination by unwittingly killing her husband and committing suicide. The novel mocks the husband's duty to sexually educate his virgin bride as Anthony gradually loses his health and cannot make love to his wife. The novel reverses gender roles, as Anthony cannot take her virginal blood and instead gives away his life energy to Harriet.

Anthony and Harriet's deaths during their honeymoon render marriage as an unhealthy institution that gives husbands the duty to treat their wives as children in need of parental control. The narrator portrays the belittlement of Victorian women as Anthony calls his orphan wife "poor little girl" and "little woman," while also adoring the kindhearted Harriet as the "sweet child of the sun" (pp. 146-168). Her unwitting power to kill Anthony destroys John Ruskin's (1865) ideal of happiness centered on "majestic childishness" of women, who should be tamed in marriage (p. 96). Ironically, Harriet gains vitality and strength not from Anthony's patriarchal authority but from his gradual sickness and decay. Blood also counters Ruskin's (1865) celebration of women's "useful years" as wives and mothers with a selfserving female vampire that usurps the energy of her husband. The gender roles are reversed as Harriet's ungovernable psychic powers emasculate Anthony, who, like a child, needs guidance and care. The newlyweds' deaths render marriage an oppressive and outdated institution that sickens and destroys Victorians at the turn of the century.

\section{The Colonial Strikes Back: Harriet Usurps the English Blood}

Other than Harriet's defiance of traditional female roles, what makes the European hotel guests sick is their encounter with the black blood that is allegedly monstrous and vampiric. Blood is alarming because it shows that English blood is not purely white, but mixed. Elaine Showalter (1991) writes: "Racial boundaries were among the most important lines of demarcation for English society; fears not only of colonial rebellion, but also of racial min- 
gling, crossbreeding, and intermarriage, fueled scientific and political interest in establishing clear lines of demarcation between black and white, East and West" (p. 5). The multiethnic and multilingual vampire, however, disturbs the clear-cut boundaries between white and black and even anticipates transnationalism, "the condition of cultural interconnectedness and mobility across space" (Ong, 1999, p. 4). The sickness of Harriet's loved ones stands for the assumption that mixed blood is a disease that spreads through marriage or immigration.

Anthony dies because, by taking a Creole wife, he goes against the purpose of marriage to produce healthy English children. Love is not a private emotion, but a social responsibility to follow the law of eugenics, which, "taken from the Greek eugenes," means "good in stock" (Richardson, 2003, p. 2). Indeed, the intermarriage of a white British man with blue eyes and a half-Creole woman turns deadly as Anthony follows his heart instead of his duty to guarantee the racial quality of his offspring. The daughter of "a fat, flabby, half caste" Jamaican woman (p. 68), Harriet does not fit into the standards of the Eugenics Society that regards whiteness to be natural: "a eugenic girl is a healthy girl, and a healthy girl is an attractive girl" (Richardson, 2003, p. 81). Harriet's former lover Captain Ralph supports the law of eugenics as he marries Elinor, not his half-Jamaican lover: "[...] she has black blood in her, her mother was a half-caste, so you see it would be impossible for any man in my position to think of marrying her! One might get a piebald son and heir" (p. 143). The racially mixed blood seems contagious, as Harriet's white British admirers - her husband and her teenage admirer Bobby - die due to their encounter with a half-Jamaican woman.

The characters' common symptoms of weakness and fainting can also be regarded as phobic reactions to a British-Creole woman with black blood. Minna Vuohelainen (2013) defines xenophobia as a chronic "irrational fear of all foreigners [...] tied to the imperial and migrational conditions of the fin de siècle which, [...] witnessed increasing contact between the British and a number of foreign peoples" (p. 315). Quoting from fin-de-siècle medical accounts on phobia, she writes that the common symptoms of xenophobia are nausea, loathing, horror, "cold perspiration," pallid countenance, weakness, and "loss of blood [or] general sickness" (p. 314). The xenophobic rhetoric of the fin de siècle can be traced in Blood, as Harriet's loved ones unwittingly react to her racial ambiguity: the nuns at the convent in Jamaica grow pale due to the presence of the white-skinned woman who resembles the colonizer; Anthony feels "weak and enervated" during their honeymoon (p. 181). Margaret's symptoms of illness also derive from her homophobic as well as xenophobic reaction to Harriet, whom she compares to a poisonous snake.

The following dialogue between the hotel guests suggests that fin-de-siècle Europe is not ready to welcome the racially unidentifiable woman:

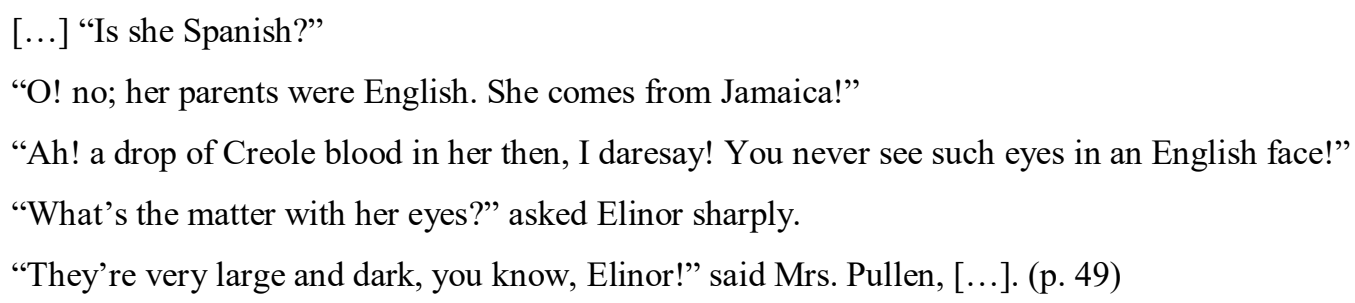

Whereas Ralph Pullen flirts with the exotic woman, the female characters elevate Victorian beauty standards by regarding her dark "long-shaped" eyes and "wide mouth" as unnatural (p. 77). Assuming that race connotes character, the ladies despise Harriet as "a half-tamed savage" (137) who is not fit for English society. The narrator, on the other hand, perceives Harriet's dark physical traits as indicators of her violent character and attributes her brutality against Elinor, while they fight over Ralph, to her Jamaican heritage: "All the Creole in her 
came to the surface [...]. Her dark eyes rolled in her passion" (p. 111). While unraveling racism in Europe, the colonial encounter teaches Victorian ladies that their homeland is not homogeneously white as they believed it to be.

Harriet herself believes in white supremacy and identifies herself English: when Margaret notices her accent, Harriet exclaims: "But I thought-I hoped - that I spoke English like an English woman! I am an Englishwoman, you know!" (p.13). She is disgusted with blackness and even prefers white babies to "nasty" "little niggers," who nauseate her with their horrible smell (p. 14). Even at the age of four, she supported British colonial power by whipping her parents' slaves at their Jamaican plantation:

"We had plenty of niggers on the coffee plantation, regular African fellows with woolly heads and blubber lips and yellow whites to their eyes. When I was a little thing of four years old Pete used to let me whip the little niggers for a treat when they had done anything wrong. It used to make me laugh to see them wriggle their legs under the whip and cry!"

“O! don’t, Miss Brandt!” exclaimed Margaret Pullen, in a voice of pain.

"It's true, but they deserved it you know, the little wretches, always thieving or lying or something!" (p. 17)

The two women's conversation on slavery reveals complex power relations in British colonialism: a social outcast herself, Harriet regards Africans as sickly "little wretches," who deserve punishment for their wrongdoings. Ironically, Margaret disapproves of slavery but supports her husband's fight for British imperialism. Indeed, both women have blood money: Harriet's father makes a fortune out of slavery in Jamaica; Margaret's husband "toil[s] out in India for baby and herself" (p. 8). When Harriet commits suicide, Margaret inherits the money that was gained through slavery on the Jamaican plantation. Even in death Harriet identifies herself an Englishwoman by leaving her blood money to Margaret to redeem herself for killing Ethel.

Having accepted white supremacy, Harriet is blind to her power to destroy the myth of the healthy and physically superior white race by inflicting Europeans with sickness. Indeed, she regards herself as a sick woman who pollutes her environment: "I am a social leper, full of contagion and death," she says (p. 177), and commits suicide, which, for Alexandra Warwick (1995), empowers Harriet as a self-prosecutor: "The voluntary nature of her death is important, it is an acknowledgement of her own guilt and her danger to others. There is no need for her to be pursued and staked like Lucy [in Dracula], she sacrifices herself [...]" (p. 219). While regarding suicide as an act of empowerment, Warwick overlooks the fact that Harriet sacrifices herself for the well-being of the white European race that is threatened by her racial hybridity. Although the colonial woman strikes back, usurps British blood, and "suck[s] them dry" (p. 162), she reaffirms British colonial power as Harriet hopes to purify the environment she allegedly contaminates by committing suicide. In her suicide note to Margaret, Harriet writes: "My parents have made me unfit to live. Let me go to a world where the curse of heredity which they laid upon me may be mercifully wiped out" (p. 187). The fact that she considers herself unfit to live in late nineteenth-century Europe suggests that she cannot survive the turbulence of the fin de siècle that shakes hierarchical racial and ethnic categories. 


\section{The Cross-Species Woman}

The racially hybrid new woman destabilizes the authority of fin-de-siècle science with her interspecies identity that is simultaneously human and vampiric. ${ }^{4}$ Hammack (2008) is surprised that Marryat's characters do not "comment on the absurdity of the vampire-bat feature of her backstory" (p. 888). However, the vampire myth that Hammack (2008) finds absurd challenges the "secular, rationalist, anti-clerical" premise that "all phenomena in the universe operated on determinable, mechanical laws, rendering any supernatural intervention or 'spiritual' entities impossible" (Ledger and Luckhurst, 2000, p. 221). A Catholic and spiritualist, Marryat herself challenged the empiricist belief that knowledge can be gained only from experience. She defended spiritualism in the periodical (London Society) she edited, and even had séances with a trance medium who allegedly helped her encounter "the spirit manifestation of her dead daughter, also called Florence, who died in 1860 at just 10 days old" (Hill, 2008 , p. 335). A prolific writer's involvement in spiritualism calls into question the enlightened image of Victorian England that is in between modernity and tradition. The novel unsettles the readers by locating spiritualism in both Europe and Jamaica and by imagining an interspecies identity that cannot be scientifically explained.

Marryat's pro-spiritualist novel imagines an inter-celestial protagonist who defies easy categorizations of animal and human with her "blood-red lips," "small white teeth" (p. 4), "boneless hands and feet" (p. 77), and her power to "suck [her] victims' breaths until they die" (p. 167). Harriet's interspecies identity is also evoked with subtle comparisons between Harriet, who has the finest voice in Jamaica, and the Sirens, the daughters of the river god in Greek mythology, who caused the shipwreck of many boats by luring the sailors to their island with a rocky coast. Doctor Phillips warns the hotel guests against Harriet by evoking the beautiful but dangerous Sirens with enchanting voices: "she is still more dangerous than I imagined her to be! Those tones would be enough to drag any man down to perdition" (p. 71). Like the Sirens, Harriet both fascinates and endangers the hotel guests "as she ran over the strings of her mandoline in a merry little tarantelle which made everyone in the room feel as if they had been bitten by the spider from which it took its name, and wanted above all other things to dance" (p. 135). Indeed, if not by a spider, the guests are metaphorically bitten by the vampiric woman, who casts them under her spell with her energy-draining powers and trances them with her dance.

Blood also challenges the Orientalist division between the "rational" England and its "magical" colonies by drawing parallels between Madame Gobelli, a fraudulent medium from London, and Harriet's voodoo Jamaican mother, who both defy Victorian ideals of decorum as "obese" and "enormous" women (p. 5). The cultural and ethnic differences between the two dissolve as the "devilish" Baroness with "bloodthirsty sentiments" (p. 31) replaces Harriet's mother and regards Harriet as her daughter. As the Baroness boasts of her magical powers that raise the dead, the novel locates "Obeah"- "folk magic, sorcery and religious practices of West African origin"-in the so-called enlightened England (p. 35). Although the Baroness falsely claims to be a medium, it is her engagement with spiritualism that protects her from Harriet's deadly powers. The hierarchical racial and class distinctions fall apart as the

\footnotetext{
4 "The fin-de-siècle Gothic consistently blurs the boundary between natural and supernatural phenomena, hesitating between scientific and occultist accountings of inexplicable events. The realm the genre explores is the grey area at the borderline between known and unknown, or extra-rational phenomena, with the supernatural defined not as the occult per se, but as the product of mysterious natural forces the scientist has not yet been able to explain" (Hurley, 1996, pp. 16-17).
} 
slaves and servants of Harriet's father's plantation, the Jamaican heiress, and London's elite all participate equally in spiritualism.

Marryat imagines a contact between the two seemingly opposing discourses of the supernatural and science, as Doctor Phillip believes in the vampire myth and lacks a scientific explanation for Harriet's psychic powers: "She possesses the fatal attributes of the Vampire that affected her mother's birth — that endued her with the thirst for blood which characterized her life - that will make Harriet draw upon the health and strength of all with whom she may be intimately associated-[...]" (p.79). Harriet's suitors discredit the doctor's assessment that paradoxically connects vampirism and science. Captain Ralph considers the doctor mad to believe that Harriet's love is deadly; Anthony dismisses the doctor's advice against his marriage to Harriet due to her vampiric lineage: "He is an old fool, a dotard, a senseless ass, and I shall tell him so! Vampire be hanged!" (p. 166). "Doctor Phillips be damned!," exclaims Anthony; ironically he himself is damned for insisting on "tenable" evidence and dismissing Harriet's own warning about her psychic powers. Marryat, in Dr. Phillips, does not portray "the esteemed superiority of medical wisdom," as Depledge (2010, p. xvii) claims, but connects science and spiritualism by having a scientist believe in vampirism and accept Harriet's abhuman identity.

Indeed, in Doctor Phillips, Marryat challenges the association of science and progress by showing how medical research in Europe involves violence. In his conversation with Margaret, the doctor unravels the brutality in Swiss hospitals, where Harriet's father Henry Brandt became a vivisector:

He was a scientist perhaps - a murderer certainly! [...] This man Brandt matriculated in the Swiss hospitals, whence he was expelled for having caused the death of more than one patient by trying his scientific experiments upon them. The Swiss laboratories are renowned for being the most foremost in Vivisection and other branches of science that gratify the curiosity and harden the heart of man more than they confer any lasting benefit on humanity. Even there Henry Brandt's barbarity was considered to render him unfit for association with civilized practitioners, and he was expelled with ignominy. (p. 68)

The novel questions the progressive nature of science as Henry Brandt vivisects his patients for medical investigation and animals for his own gratification. Having met him in Jamaica, Dr. Phillips tells Margaret how Henry tortured and imprisoned natives in his Pandemonium, the capital of Hell in John Milton's Paradise Lost (p. 68), until his servants took revenge by slaughtering him. Ironically, the Doctor vicariously enjoys the murder of Henry and his mistress "in the most torturing fashion" the servants could have devised" (p. 77). The science of the fin de siècle no longer seems secular and progressive as the doctor curses the "godless" (p. 69) vivisector, who uses science not for humanity's benefit but to gratify his desire for violence.

\section{Conclusion}

Overall, embodying the turbulence of the fin de siècle, Harriet Brandt's liminal identity creates motion sickness in the characters (and the Victorian readers) by shaking socially constructed categories of race, gender, and species. John Ruskin (1853) laments that the unified, fixed, and harmonious notion of identity will fall apart in the modern era: "[...] men:Divided into mere segments of men — broken into small fragments and crumbs of life [...]" (p. 87). Harriet exemplifies Ruskin's envision of a fragmented identity as a British-Jamaican heiress, a human and a vampire, a former convent girl with an unclear sexual orientation. At the beginning of the novel, the "loud and discordant bell" (p. 3) that invites the hotel guests to dinner is an indicator that the Victorian ideals of symmetry, regulation, and moral propriety are about to crumble with the arrival of a mixed woman with an unclassifiable identity. The single female traveler's homelessness and her temporary stays at the hotels also stand for her 
traveling identity that is always on the move. Indeed, the hotel guests show symptoms of vomiting - dizziness and nausea - because they are repelled by the destabilization of patriarchal gender roles and cultural differences between the enlightened England and its "backward" colonies. With Harriet's psychic vampirism, Marryat shows how sexually decadent women and ethnic minorities are cast as monstrous entities that inflict death and sickness on Victorians. The doctor's belief in Harriet's vampiric lineage is also terrifying because it paradoxically connects spiritualism and science. The trope of infection in Blood serves as a metaphor for the turbulent transitional period that drains the life energy of those who dread changing gender roles, the interconnection between England and Jamaica, and the rise of spiritualism that defies scientific authority.

\section{References}

Ardis, A. (1990). New women, new novels: feminism and early modernism. New Brunswick: Rutgers University Press.

Bhabha, H. (1994). The location of culture. London: Routledge.

Bordo, S. (1993). Unbearable weight: feminism, western culture, and the body. Berkeley: University of California Press.

Brody, J. D. (1998). Impossible purities: blackness, femininity, and Victorian culture. Durham: Duke University Press.

Cunningham, G. (1978). The new woman and the Victorian novel. London: The Macmillan Press.

Darwin, C. (2002). From 'On the origin of species.' In D. Mermin \& H. Tucker (Eds.), Victorian literature, 1830-1900 (pp. 493-501). Harcourt College Publishers.

Davis, O. (2007). Morbid mothers: gothic heredity in Florence Marryat's The Blood of the Vampire. In R. Anolik (Ed.), Horrifying sex: essays on sexual difference in gothic literature (pp. 40-54). London: McFarland.

Depledge, G. (2010). Introduction. In The Blood of the Vampire (pp. iii-xxxv). Brighton: Victorian Secrets.

Hall, S. (1996). Cultural identity and diaspora. In P. Mongia (Ed.), Contemporary postcolonial theory: a reader (pp. 110-122). London: Arnold.

Hammack, B. M. (2008). Florence Marryat's female vampire and the scientizing of hybridity. SEL Studies in English Literature 1500-1900, 48(4), 885-896.

Heilmann, A. (2000). New woman fiction: women writing first-wave feminism. London: Macmillan Press.

Hill, G. (2008). 'Above the breath of suspicion': Florence Marryat and the shadow of the fraudulent trance medium. Women's Writing 15 (3), 333-347.

Hurley, K. (1996). The gothic body: sexuality, materialism, and degeneration at the fin de siècle. New York: Cambridge University Press.

Ledger, S. (1997). The new woman: fiction and feminism at the fin de siècle. Manchester: Manchester University Press.

Ledger, S. (1995). The new woman and the crisis of Victorianism. In S. Ledger \& S. McCracken (Eds.), Cultural politics at the fin de siècle (pp. 22-45). Cambridge: Cambridge University Press. 
Ledger, S. \& Luckhurst R. (2000). Scientific Naturalism. In S. Ledger \& R. Luckhurst (Eds.), The fin de siècle: a reader in cultural history c.1880-1900 (pp. 221-223). Oxford: Oxford University Press.

Macfie, S. (1991). They suck us dry: a study of late nineteenth-century projections of vampiric women. In P. Shaw \& P. Stockwell (Eds.), Subjectivity and literature from the Romantics to the present day (pp. 58-67). London: Pinter Publishers.

Marryat, F. (2010). The Blood of the Vampire. Brighton: Victorian Secrets.

Matthias, B. (2004). A home away from home? The hotel as space of emancipation in early twentieth-century Austrian bourgeois literature. German Studies Review 27(2), 325-340.

Michie, H. (2001). Victorian honeymoons: Sexual reorientations and the 'sights' of Europe. Victorian Studies, Winter, 229-250.

Noble, J. (1895). The fiction of sexuality. Contemporary Review, 6, 490-498.

Ong, A. (1999). Flexible citizenship: The cultural logics of transnationality. Durham: Duke University Press.

Pratt, M. L. (1992). Imperial eyes: travel writing and transculturation. London: Routledge.

Richardson, A. (2003). Love and eugenics in the late nineteenth century: rational reproduction \& the New Woman. Oxford: Oxford University Press.

Ruskin, J. (1916). Lilies of queen's gardens. In Sesame and lilies: three lectures (pp. 81-114). New York: American Book Company.

Ruskin, J. (1985). The nature of gothic. In C. Wilmer (Ed.), Unto this last and other writings (pp. 77-111). London: Penguin.

Showalter, E. (1991). Sexual anarchy: gender and culture at the fin de siècle. New York: Penguin Books.

Warwick, A. (1995). Vampires and the empire: fears and fictions of the 1890s. In S. Ledger \& S. McCracken (Eds.), Cultural politics at the fin de siècle (pp. 202-221). Cambridge: Cambridge University Press.

Winston, E. (2001). Foibles of the New Woman [Forum 21 (April 1896): 186-92). In C. Nelson (Ed.), A new woman reader (pp.170-176). Ontario: Broadview Press.

Williams, R. (1963). Culture and society. Harmondsworth: Penguin.

Vuohelainen, M. (2013). 'You know not of what you speak:' language, identity, and xenophobia in Richard Marsh's The Beetle: A Mystery (1897). In M. Tromp, M. Bachman, and H. Kaufman (Eds.), Fear, loathing, and Victorian xenophobia (pp. 312-331). Columbus: Ohio State University Press.

Zieger, S. (2008). Inventing the addict: drugs, race and sexuality in nineteenth-century British and American literature. Amherst: University of Massachusetts Press. 